\title{
PENYAKIT RINOSINUSITIS SEBAGAI KOMPLIKASI PADA PENDERITA RINITIS ALERGI POLI KLINIK THT RSUD A. DADI TJOKRODIPO BANDAR LAMPUNG PERIODE JANUARI 2016 - DESEMBER 2017
}

\author{
Arti Febriyani Hutasuhut ${ }^{1}$, David Ari Wibowo Simaremere ${ }^{2}$ \\ ${ }^{1}$ Departemen Imunologi, Fakultas Kedokteran, Universitas Malahayati \\ ${ }^{2}$ Prodi Kedokteran, Fakultas Kedokteran, Universitas Malahayati
}

\begin{abstract}
Rhinosinusitis as Complications in Patients with Poly Allergy Rhinitis ENT Clinic A. Dadi Tjokrodipo Hospital Bandar Lampung Period January 2016 - December 2017. Allergic rhinitis (RA) is a disease that is often found in the community. The main symptoms are sneezing, runny nose (rhinorrhea), and nasal congestion. The purpose of this study was to determine whether allergic rhinitis, cigarette smoke exposure environment, and having a pet are factors that influence the incidence of rhinosinusitis in patients with allergic rhinitis. The study sample was all patients with a diagnosis of allergic rhinitis in RSUD A. Dadi Tjokrodipo who met the inclusion criteria using a random sampling technique of 75 patients. From a sample of 75 allergic rhinitis patients, $67(89.3 \%)$ were positive for rhinosinusitis while $8(10.7 \%)$ were negative. There were 53 people $(70.7 \%)$ exposed to positive cigarette smoke having rhinosinusitis, while 22 people $(29.3 \%)$ were never exposed to negative cigarette smoke from rhinosinusitis. There were 56 people $(74.7 \%)$ who kept pets positive for rhinosinusitis while 19 people $(25.3 \%)$ did not have negative pets for rhinosinusitis. There is a significant relationship between patients with allergic rhinitis with pet ownership of risk factors for rhinosinusitis with a positive correlation level of 0.295.
\end{abstract}

Keywords: Rhinitis, symptoms, prevalence.

Abstrak: Penyakit Rinosinusitis Sebagai Komplikasi Pada Penderita Rinitis Alergi Poli Klinik THT RSUD A. Dadi Tjokrodipo Bandar Lampung Periode Januari 2016 - Desember 2017. Rinitis alergi (RA) adalah penyakit yang sering dijumpai di masyarakat. Gejala utamanya adalah bersin, hidung beringus (rhinorrhea), dan hidung tersumbat. Tujuan penelitian adalah mengetahui apakah rinitis alergi, lingkungan paparan asap rokok, dan memiliki hewan peliharaan adalah faktor yang berpengaruh terhadap kejadian rinosinusitis pada penderita rinitis alergi. Sampel penelitian adalah semua pasien dengan diagnosis rinitis alergi di RSUD A. Dadi Tjokrodipo yang memenuhi kriteria inklusi menggunakan teknik random sampling yaitu sebanyak 75 pasien. Dari sampel sebanyak 75 orang pasien rinitis alergi didapat 67 orang $(89,3 \%)$ positif rinosinusitis sedangkan 8 orang $(10,7 \%)$ negatif. Terdapat 53 orang $(70,7 \%)$ terpapar asap rokok positif memiliki rinosinusitis, sedangkan 22 orang $(29,3 \%)$ tidak pernah terpapar asap rokok negatif rinosinusitis. Didapatkan 56 orang $(74,7 \%)$ yang memelihara hewan peliharaan positif rinosinusitis sedangkan 19 orang $(25,3 \%)$ tidak memiliki hewan peliharaan negatif rinosinusitis. Terdapat hubungan yang signifikan antara penderita rinitis alergi dengan kepemilikan hewan peliharaan terhadap faktor risiko terjadinya rinosinusitis dengan tingkat korelasi positif 0,295.

Kata kunci : Rinitis, gejala, prevalensi. 


\section{PENDAHULUAN}

Rinitis alergi adalah penyakit simtomatis pada membran mukus hidung akibat inflamasi yang dimediasi oleh Imunoglobulin $E$ (IgE) pada lapisan membran yang diinduksi oleh paparan alergen. Pada tahun 1929 ditetapkan 3 gejala utamanya antara lain bersin-bersin, hidung tersumbat dan keluarnya sekret hidung.

Berdasarkan rekomendasi dari WHO Iniative ARIA (Allergic Rhinitis and its Impact on Asthma) tahun 2001, yaitu berdasarkan sifat berlangsungnya dibagi menjadi : 1) Intermiten (kadang-kadang) bila gejala kurang dari 4 hari/minggu atau kurang dari 4 minggu. 2) Persisten/menetap bila gejala lebih dari 4 hari/minggu dan atau lebih dari 4 minggu.

Sedangkan untuk tingkat berat ringannya penyakit, rinitis alergi dibagi menjadi: 1) Ringan, bila tidak ditemukan gangguan tidur, gangguan aktivitas harian, bersantai, berolahraga, belajar, bekerja dan halhal lain yang mengganggu. 2) Sedang atau berat bila terdapat satu atau lebih dari gangguan tersebut di atas (Bousquet, J. et al, 2013).

Berdasarkan penelitian ditemukan bahwa kelompok umur dengan frekuensi terbanyak pada $18-35$ tahun. Penderita perempuan lebih banyak (54,1\%) dibandingkan laki-laki $(45,9 \%)$ dengan perbandingan RA intermiten dengan persisten $1: 5$. Manifestasi RA terbanyak adalah RA persisten sedang - berat yaitu sebesar 59,5\% (Utama, D.S, 2012).

Selain mengakibatkan gejala lokal pada hidung, juga dapat mengakibatkan gejala sistemik berupa rasa lelah, mengantuk di siang hari, gangguan kognitif, nyeri kepala, dan pada beberapa kasus berat penderita dapat mengalami depresi sehingga mempengaruhi kualitas hidup penderita. Rinitis alergi persisten sedang berat dapat mengakibatkan keluhan mengantuk di siang hari seperti dilaporkan $23 \%$ penderita rinitis alergi persisten sedang berat di klinik THT RS RSUP Dr Kariadi. Keluhan mengantuk meningkat menjadi 46,37
$\%$ pada penderita yang mendapatkan anti alergi yang memiliki efek samping sedasi. Pada anak-anak penderita rinitis alergi, gangguan belajar saat jam sekolah dapat terjadi baik karena secara langsung akibat kurang tidur di malam hari, atau secara tidak langsung karena rasa capai di siang hari.

Rinitis alergi merupakan penyakit multifaktorial yang meliputi interaksi antara faktor genetik dan lingkungan. Faktor genetik pada rinitis alergi dapat dilihat dari hubungan fenotip yang erat antara pilek alergi dan asma bronkial (penyakit diturunkan). Penyakit alergi bersifat diturunkan dalam keluarga. Jika hanya salah satu orang tuanya menderita alergi, maka risiko anaknya terkena alergi adalah $50 \%$. Dan jika kedua orang tua memiliki alergi, risiko anaknya terkena alergi adalah $75 \%$. Penelitian dengan imigran sebagai subyek, menunjukkan bahwa terdapat faktor genetik yang mempengaruhi pola IgE yang diturunkan dari orang tua, khususnya dari ibu (Pawankar R, 2011).

Faktor risiko rinitis alergi dari lingkungan berupa paparan alergen. Berdasarkan penelitian di RSCM, diperoleh data $59 \%$ sensitivitas terhadap alergen inhalan dan $49 \%$ terhadap alergen makanan. Aeroalergen yang tersering dengan hasil uji cukit kulit positif pada penelitian di klinik THT - KL RSUP Dr Kariadi adalah kecoa (44,6 \%), disusul mite culture $(40,5 \%)$, house dust $(25,7 \%)$, cat dander $(16,2 \%)$ dan dog dander $(5,4 \%)$. Penelitian menunjukkan bahwa odd ratio rinitis alergi lebih tinggi pada anak yang memelihara hewan, terutama anjing (Wright A L. et al, 2012).

Reaksi hipersensitivitas pada mukosa hidung yang memicu bermacam-macam respon hidung terhadap paparan alergen merupakan proses dinamis yang disebabkan oleh alergen yang spesifik. Pada proses ini terlibat berbagai macam tipe sel, mediator, dan mekanisme yang berbeda pada setiap jenjang dan level yang berbeda (Pelikan Z, 1994). 
Rinitis alergi merupakan suatu penyakit inflamasi yang diawali dengan tahap sensitisasi dan diikuti dengan reaksi alergi. Reaksi alergi terdiri dari 2 fase yaitu immediate phase allergic reaction atau reaksi alergi fase cepat (RAFC) yang berlangsung sejak kontak dengan alergen sampai 1 jam setelahnya dan late phase allergic reaction atau reaksi alergi fase lambat (RAFL) yang berlangsung 2 - 4 jam dengan puncak $6-8$ jam (fase hipereaktivitas) setelah pemaparan dan dapat berlangsung $24-48$ jam (A.S Efiaty. et al, 2007).

\section{HASIL}

\section{Analisis Univariat}

Analisis univariat dalam penelitian ini dilakukan untuk menilai dan mengetahui karakteristik responden penelitian pada masing-masing variabel. Hasil analisis ini nantinya akan memberikan gambaran dari masing-masing variabel yang diteliti.

Peneliti mendapat data penderita rinitis alergi yang memiliki komplikasi rinosinusitis dan yang tidak memiliki komplikasi rinosinusitis di RSUD A Dadi Tjokrodipo tahun 2018. Berdasarkan tabel 1 di bawah menunjukkan bahwa dari jumlah sampel sebanyak 75 orang pasien rinitis alergi didapat 67 orang dengan persentase $89,3 \%$ positif rinosinusitis sedangkan sebanyak 8 orang atau $10,7 \%$ negatif.

Tabel 1. Distribusi Penderita Rinitis Alergi yang Memiliki Komplikasi Rinosinusitis dan Tidak Memiliki Komplikasi Rinosinusitis

\begin{tabular}{|c|c|c|c|}
\hline Variabel & Rinitis Alergi & Frekuensi (N) & Persentase (\%) \\
\hline Rinosinusitis & $\begin{array}{c}\text { Ya } \\
\text { Tidak }\end{array}$ & $\begin{array}{c}67 \\
8 \\
75 \\
\end{array}$ & $\begin{array}{c}89,3 \\
10,7 \\
100 \\
\end{array}$ \\
\hline \multicolumn{4}{|c|}{$\begin{array}{l}\text { Tabel 2. Distribusi Penderita Rinitis Alergi yang Terpapar Asap Rokok da } \\
\text { yang Tidak Terpapar Asap Rokok }\end{array}$} \\
\hline Variabel & Terpapar asap rokok & Frekuensi (N) & Persentase (\%) \\
\hline Rinosinusitis & $\begin{array}{l}\text { Ya } \\
\text { Tidak }\end{array}$ & $\begin{array}{l}53 \\
22 \\
75\end{array}$ & $\begin{array}{c}70,7 \\
29,3 \\
100\end{array}$ \\
\hline
\end{tabular}

METODE

Sampel penelitian adalah sebagian yang diambil dari keseluruhan objek yang diteliti dan dianggap mewakili keseluruhan populasi (Notoatmodjo S, 2010). Dalam penelitian ini yang dijadikan sampel adalah semua pasien dengan diagnosis rinitis alergi di RSUD A. Dadi Tjokrodipo yang memenuhi kriteria inklusi menggunakan teknik random sampling dengan rumus yang digunakan adalah Rumus Slovin. Jumlah sampel pasien pada penelitian ini sebanyak 75 sampel.

Peneliti mendapat data penderita rinitis alergi yang terpapar asap rokok dan yang tidak terpapar asap rokok di RSUD A Dadi Tjokrodipo tahun 2018. Berdasarkan tabel 2 di bawah menunjukkan bahwa dari jumlah sampel sebanyak 75 orang pasien persentase $70,7 \%$ mengaku sering terpapar asap rokok ataupun seorang perokok dan positif memiliki rinosinusitis, sedangkan sisanya sebanyak 22 orang atau 29,3\% mengaku tidak pernah terpapar asap rokok ataupun merokok negatif rinosinusitis. rinitis alergi didapat 53 orang dengan 
Peneliti mendapat data penderita rinitis alergi yang memelihara hewan peliharaan dan yang tidak memelihara hewan peliharaan di RSUD A Dadi Tjokrodipo tahun 2018. Berdasarkan tabel 3 di bawah menunjukkan bahwa dari jumlah sampel sebanyak 75 orang pasien rinitis alergi didapat 56 orang dengan persentase $74,7 \%$ yang memelihara hewan peliharaan positif rinosinusitis sedangkan sebanyak 19 orang atau $25,3 \%$ tidak memiliki hewan peliharaan negatif rinosinusitis.

\section{Tabel 3. Distribusi Penderita Rinitis Alergi yang Memelihara Hewan Peliharaan dan Rinosinusitis}

\begin{tabular}{|c|c|c|c|}
\hline Variabel & Memelihara hewan & Frekuensi (N) & Persentase (\%) \\
\hline Rinosinusitis & $\begin{array}{c}\text { Ya } \\
\text { Tidak }\end{array}$ & $\begin{array}{l}56 \\
19 \\
75\end{array}$ & $\begin{array}{c}74,7 \\
25,3 \\
100\end{array}$ \\
\hline
\end{tabular}

\section{Analisis Univariat}

Analisis bivariat digunakan untuk menampilkan tabulasi silang yang menunjukkan suatu distribusi bersama dan pengujian terhadap dua variabel atau lebih (Sujarweni, 2015). Uji statistik yang digunakan dalam penelitian ini adalah dengan uji regresi linear, yaitu suatu uji untuk mengetahui signifikansi pengaruh variabel bebas (independent) terhadap variabel terikat (dependent) (Ghozali, 2011).

Berdasarkan hasil penelitian yang telah dilakukan menggunakan uji regresi linear menunjukkan bahwa terdapat hubungan bermakna namun tidak signifikan antara penderita rinitis

\section{PEMBAHASAN}

Kejadian rinosinusitis meningkat seiring meningkatnya kasus rinitis alergi. Hal ini di sebabkan karena pembengkakan mukosa hidung pada rinitis alergi di ostium sinus dapat mengganggu ventilasi bahkan menyumbat ostium sinus yang mengakibatkan retensi sekret mukus dan infeksi (Suprihati, 2010). Berdasarkan penelitian dengan pemeriksaan CT scan, terdapat $78 \%$ penderita rinosinusitis yang memiliki komorbid rinitis alergi. Hubungan antara faktor alergi dan beratnya gejala rinosinusitis berdasarkan alergi terhadap faktor risiko terjadinya rinosinusitis karena nilai $p>0,005$, terdapat hubungan bermakna namun tidak signifikan antara penderita rinitis alergi yang terpapar asap rokok terhadap faktor risiko terjadinya rinosinusitis karena nilai $p>0,005$ dan terdapat hubungan yang bermakna signifikan antara penderita rinitis alergi yang memiliki hewan peliharaan terhadap faktor risiko terjadinya rinosinusitis karena nilai $p<0,005$ dengan tingkat korelasi positif 0,295 yang artinya penderita rinitis yang memiliki hewan peliharaan lebih berisiko menderita rinosinusitis.

pemeriksaan CT scan, terbukti bahwa jika terdapat faktor alergi pada rinitis alergi kronik, maka semakin berat gejala rinosinusitisnya (Suprihati, 2010). Penelitian belum lama ini membuktikan bahwa mukosa hidung yang terpapar alergen akan memicu inflamasi sinus maksilaris sekunder. Rinitis alergi tidak hanya menunjukkan tanda inflamasi pada mukosa hidung saja tetapi juga inflamasi kronis mukosa sinus, terutama pada rinitis alergi persisten yang profil inflamasinya terlihat lebih lambat dibandingkan dengan rinitis alergi intermiten. Rinitis 
alergi dinyatakan persisten apabila gejala lebih dari 4 hari/minggu dan atau lebih dari 4 minggu. Dinyatakan intermiten apabila gejala kurang dari 4 hari/minggu dan atau kurang dari 4 minggu. Dalam penelitian ini seluruh pasien dengan rinitis alergi berjumlah 75 orang pasien rinitis alergi didapat 67 orang dengan presentase 89,35\% positif rinosinusitis sedangkan sebanyak 8 orang atau $10,7 \%$ negatif. Setelah dilakukan analisis statistik dengan uji regresi diperoleh nilai $p$ 0,035 , di mana nilai tersebut $>0,005$ memiliki tingkat pengaruh negatif yaitu $-0,159$ yang berarti terdapat hubungan bermakna namun tidak signifikan.

Asap rokok dapat meningkatkan IgE spesifik maupun IgE total. Berdasarkan penelitian Butland et al, diperoleh kesimpulan bahwa paparan asap rokok prenatal dan awal prenatal dapat memicu sensitivitas alergi pada 3 tahun pertama kehidupan (Butland et al, 1997). Beberapa perokok dilaporkan memiliki gejala sensitivitas terhadap asap rokok seperti nyeri kepala dan iritasi hidung (rinore, hidung tersumbat, post natal drip, dan bersin bersin) (Annesi-Maesano I, Oryszczyn MP, Neukirch F, Kauffmann F, 1997).

Asap rokok dapat mengganggu klirens mukosiliar dan mengakibatkan inflamasi yang mirip seperti alergi bahkan pada orang yang nonatopi. Pada penderita rinitis alergi yang menjadi perokok pasif, asap rokok dapat memicu munculnya gejala rinitis (Spector SL, 1997). Orang yang memiliki anggota keluarga perokok memiliki episode penyakit saluran pernafasan akut lebih sering (termasuk rinosinusitis). Terdapat hasil berbeda bermakna antara subyek yang memiliki keluarga merokok lebih dari atau sama dengan 45 batang per hari dengan subyek yang tidak memiliki keluarga yang merokok. Diperoleh kesimpulan bahwa semakin tinggi konsumsi rokok, semakin tinggi predisposisi terjadinya penyakit saluran nafas. Berdasarkan penelitian oleh Eyigur dan Basak dilaporkan bahwa paparan asap rokok baik aktif maupun pasif merupakan faktor predisposisi terjadinya rinosinusitis akut (Eyigor $\mathrm{H}$, Basak $\mathrm{S}$, 2015).

Dalam penelitian sebagian besar penderita rinitis alergi berada pada lingkungan rentan terpapar asap rokok yaitu 53 orang. Penderita rinitis alergi yang berada pada lingkungan yang tidak terpapar asap rokok sebanyak 22 orang. Setelah dilakukan analisa statistik diperoleh nilai $p=0,010$ atau $p>0,005$. Hasil tersebut menunjukkan bahwa lingkungan yang terpapar asap rokok terbukti sebagai faktor risiko terjadinya rinosinusitis pada penderita rinitis alergi namun secara statistik menunjukkan angka tidak signifikan. Hal ini mungkin dikarenakan subyek tidak terpapar asap rokok terus menerus dalam waktu yang cukup lama setiap hari. Selain itu juga tidak diketahuinya jumlah rokok yang dikonsumsi oleh perokok di sekitar subyek, sehingga tidak dapat diperkirakan jumlahnya banyak atau sedikit.

Dander atau sekresi dari anjing dan kucing membawa alergen yang berpotensi besar menjadi penyebab alergi. Sumber alergen yang terdapat pada kucing dan anjing adalah pada kelenjar sebasea, saliva dan kelenjar peri-anal, dan bulu kucing atau anjing. Protein yang terdapat di saliva dan urin adalah sumber utama alergen yang berasal dari hewan peliharaan. Kelenjar sebasea hewan juga memproduksi protein yang sama. Kucing dan anjing jantan memiliki sekresi lebih banyak dan bersifat lebih alergenik dibandingkan yang betina. Serpihan kulit dan saliva mengandung banyak protein larut dalam air yang mengakibatkan reaksi alergi. Bulu hewan memiliki sedikit protein larut dalam air kecuali jika bulunya terkontaminasi oleh saliva ketika hewan menjilat bulunya. Alergen yang berasal dari hewan dapat bertahan selama 6 bulan bahkan lebih setelah hewan peliharaan tidak lagi berada di tempat itu. Beberapa alergen dapat bertahan hingga beberapa tahun karena terkontaminasi urin dapat menempel di karpet, perabotan rumah tangga, dan lantai. Selain itu serpihan 
kulit hewan dapat tersebar bahkan hingga tempat yang tersembunyi seperti saluran air, loteng, kadang sela-sela alat-alat perabotan rumah tangga (Utama, D.S, 2010). Pasien yang memiliki alergi terhadap kucing dan anjing sering menunjukkan reaktivitas IgE terhadap paparan alergen dari hewan berbeda. Umumnya ditemukan IgE spesifik terhadap kucing dan anjing (Spector, SL, 1997).

Pada penelitian ini jumlah penderita rinitis alergi yang memiliki hewan peliharaan lebih banyak dibanding yang tidak memiliki hewan peliharaan, dari jumlah sampel sebanyak 75 orang pasien rinitis alergi didapat 56 orang dengan persentase $74,7 \%$ yang memelihara hewan peliharaan positif rinosinusitis sedangkan sebanyak 19 orang atau $25,3 \%$ tidak memiliki hewan peliharaan negatif rinosinusitis. Secara statistik terdapat risiko bermakna signifikan antara memiliki hewan peliharaan dengan kejadian rinosinusitis pada penderita rinitis alergi dengan nilai tingkat korelasi positif 0,295 dan nilai $p<0,005$. Hasil tersebut berarti penderita rinitis alergi yang memiliki hewan peliharaan berisiko mengalami rinosinusitis sehingga dapat ditarik kesimpulan bahwa memiliki hewan peliharaan adalah faktor risiko kejadian rinosinusitis pada penderita rinitis alergi.

Alergi terhadap kucing lebih sering ditemukan dan gejala umumnya lebih berat. Hipereaktivitas terhadap kucing dapat mencapai $25 \%$ dari seluruh kasus alergi. Alergen utama dari kucing ( $F e l d 1$ ) terdapat di saliva, darah, serpihan kulit dan ekskresi kelenjar sebasea. Serpihan kulit kucing sangat ringan, kecil, dan dapat menempel kuat. Selain fel $d$, juga terdapat alergen fel $d 2$ yang berasal dari kucing. Alergen utama pada anjing (Can $f$ 1) terdapat di bulu, saliva, kulit dan urin anjing. Alergen ini akan tersebar melalui udara bebas. Sehingga alergen tersebut dapat ditemukan di debu rumah, perabotan dan kasur. Selain itu juga terdapat alergen Can $f$
2. Umumnya anjing yang berbulu banyak dan panjang menyebabkan kontaminasi ruangan yang lebih dibandingkan anjing yang berbulu sedikit dan pendek (Bosquet J, et al, 2008).

Selain kucing dan anjing, hamster juga merupakan hewan peliharaan pembawa alergen. Alergen dapat ditemukan di bulu, urin dan saliva hamster. Berdasarkan penelitian ditemukan bahwa hamster dapat menyebabkan sensitivitas eksponensial pada pekerja laboratorium yaitu sekitar 10 sampai $40 \%$ dari pekerja laboratorium dan juga berefek pada anak yang pekerjaan orang tuanya melakukan kontak atau terpapar hamster atau mencit (Bosquet J, et al, 2008). Alergen yang terus menerus ada di sekitar penderita rinitis alergi menyebabkan inflamasi mukosa nasi terus berlangsung. Pembengkakan mukosa hidung pada rinitis alergi di ostium sinus dapat mengganggu ventilasi bahkan menyumbat ostium sinus, yang akan mengakibatkan retensi sekret mukus dan infeksi (Suprihati, 2001). Mukosa hidung dan sinus membentuk suatu rangkaian kesatuan, sehingga membran sinus sering terlibat pada penyakit yang disebabkan inflamasi pada mukosa nasi (Spector SL, 1997). Organ yang membentuk KOM letaknya berdekatan dan bila terjadi edema, mukosa yang berhadapan akan saling bertemu sehingga saliva tidak dapat bergerak dan ostium tersumbat. Sumbatan di ostium sinus dapat diakibatkan edema yang terjadi sekunder karena adanya inflamasi traktus respiratorius atau (hidung). Akibatnya terjadi penurunan sekresi sinus, penurunan tekanan $\mathrm{O} 2$ dalam sinus, hipooksigenasi dan pada akhirnya terjadi vasodilatasi kapiler sebagai mekanisme kompensasi. Penurunan ini memicu terjadinya transudasi. Sebagian cairan transudat akan masuk ke sub mukosa sehingga menyebabkan edema, sebagian lagi menuju ekstra vaskuler menembus epitel sehingga masuk ke rongga sinus. Akibatnya akan terdapat cairan transudat di rongga sinus yang mula- 
mula serous. Keadaan ini disebut rinosinusitis non bakterial (Suprihati, 1997).

Bila kondisi menetap, sekret
yang terkumpul dalam sinus merupakan media yang baik untuk tumbuhnya dan multiplikasi bakteri. Sekret menjadi purulen yang berwarna kuning kehijauan. Keadaan sinus yang hipooksigen juga dapat mengganggu gerakan silia sehingga mekanisme klirens mukosiliar terganggu. Akibatnya cairan transudat tidak dapat didrainase dan semakin tertimbun di dalam sinus. Keadaan ini membuat sinus menjadi asam dan mendukung aktivitas multiplikasi bakteri. Keadaan demikian disebut rinosinusitis bakterial (Andrianto P, 1993).

\section{KESIMPULAN}

Dari penelitian di wilayah Rumah Sakit A Dadi Tjokrodipo Bandar Lampung tahun 2018 tentang penyakit rinosinusitis sebagai salah satu komplikasi pada penderita rinitis alergi dapat disimpulkan:

1. Penderita rinitis alergi yang memiliki hewan peliharaan, dan lingkungan terpapar dengan asap rokok, berpeluang memiliki faktor resiko rinosinusitis dan sebaliknya.

2. Terdapat hubungan bermakna namun tidak signifikan antara faktor penderita rinitis alergi dengan kasus rinosinusitis dilihat dari tabel korelasi yang menunjukan angka $-0,208$ dan angka signifikan 0,035 > 0,005.

3. Terdapat hubungan bermakna namun tidak signifikan antara faktor asap rokok dengan kasus rinosinusitis karena tingkat signifikannya $0,010>0,005$ dan tingkat korelasinya yaitu 0,252.

4. Terdapat hubungan bermakna signifikan antara faktor memiliki hewan peliharaan dengan kasus rinosinusitis karena nilai $p$ signifikan yaitu 0,005 dan tingkat korelasi positif 0,295.

\section{SARAN}

Perlu diupayakan peningkatan promosi kesehatan berupa penyuluhan mengenai rinitis alergi dan rinosinusitis serta faktor penyebab terjadinya dan cara pencegahannya, himbauan mengenai pemeliharaan hewan yang baik, serta penyuluhan tentang bahaya asap rokok, melalui kelompok maupun perorangan atau dengan menggunakan media lain yang dianggap efektif sehingga dapat menekan perkembangan angka penderita rinitis alergi dan rinosinusitis sehingga pada akhirnya penyakit rinitis alergi maupun rinosinusitis tidak lagi menjadi masalah kesehatan di Indonesia khususnya di wilayah Bandar Lampung.

\section{DAFTAR PUSTAKA}

A.S Efiaty, I Nurbaiti, B Jenny, D. R, Ratna. 2007. Buku ajar ilmu kesehatan telinga hidung tenggorok kepala \& Leher. 6th ed. Jakarta: Fakultas Kedokteran Universitas Indonesia.

AAAAI. 2013. Academy of Allergy Asthma \& Immunology; condition and treatments. Di akses pada tanggal 09 Desember 2017. http://www.aaaai.org/conditionsand-treatments/library/ataglance/rhinitis.aspx

Adhika T. 2011. Hubungan perilaku merokok terhadap kekambuhan rinitis alergi. Semarang : Fakultas Kedokteran

Universitas Diponegoro; .

Andrianto P. 1993. Penyakit telinga hidung dan tenggorokan. Jakarta: EGC;

Annesi-Maesano I, Oryszczyn MP, Neukirch F, Kauffmann F. 1997. Relationship of upper airway disease to tobacco smoking and allergic markers: a cohort study of men followed up for 5 years. In Arch Allergy Immunol ;114:193 201.

Assanasen P, Naclerio RM. 2008. Cold, dry air and hyper osmolar challenges in rhinitis. Di akses pada tanggal 10 Desember 2017 
http://www.springerlink.com/co ntent/p5n6q22310615512/

Azis A, Margiyati. 2007. Gambaran Umum Pasien Suspek Rinitis Alergi Berdasarkan Tes Cukit Kulit Alergen Inhalan di Poli Alergi Imunologi RSWS Makassar. Dalam: Makalah Kongres Nasional $X V$ PERHATI KL Perhimpunan Dokter Spesialis THT-KL Indonesia.

Babar-Craig H, Gupta Y, Lund VJ. 2010. British Rhinological Society audit of the role of antibiotics in complications of acute rhinosinusitis: a national prospective audit. Rhinology.; 48 (3) :344 - 347.

Berger W E. 2004. Allergic rhinitis in children. Pediatric Drugs Journal. ; 6(4), p $233-250$.

Bousquet J. et al. 2008 Allergic rhinitis and its impact on Asthma (ARIA) update Allergy. 63 (Suppl. 86): 8 - 160. Di akses pada tanggal 09 Desember 2017.

http://www.unifesp.br/dmed/clim ed/liga/consensos/rinitealergicaea sma2008.PDF

Bousquet J, Cauwenberge P V. 2013. Allergic rhinitis and its impact on asthma (ARIA). In collaboration with the world health organisation. J Primary Care Respiratory; 11 (1) :18 - 19. Di akses pada tanggal 09 Desember 2017

http://www.thepcrj.org/journ/vol $11 \quad 1 / 0018 \quad 0019$ bousquet.pdf

Cruz AA, Naclerio RM, Proud D, Togias A. 2006. Ephithelial shedding is associated with nasal reaction to cold, dry air. J Allergy Clin Immunol; 117:1351 - 81.

David R. 2001. Perbandingan Efektifitas Antara Loratadine dan Chlorpheniramine Maleat Terhadap Kualitas Hidup Penderita Rinitis Alergi Perenial. Semarang : Fakultas Kedokteran Universitas Diponegoro.

Donald C, David W. 1994. Nose and sinus mucosal inflammation and infection, including medical therapy, Current Review of
Otolaryngology and Head and Neck Surgery; 2 : 27 - 32.

Eyigor H, Basak S. 2005. Evaluation of predisposing factors and bacteriologic agents in pediatric rhinosinusitis. Kulak Burun Bogaz Ihtis Derg.;15(3-4):49-55.

Fokkens W, Lund V, Mullol J. 2007. European position paper on rhinosinusitis and nasal polyps. Rhinol Suppl. (20):1 - 136.

Fokkens W, Lund V, Mullol J. 2012. European position paper on rhinosinusitis and nasal polyps. 50 (Suppl. 23) :17.

Ghozali, Imam. (2011). Aplikasi Analisis Multivariate Dengan Program IBM SPSS 19 (edisi kelima). Semarang: Universitas Diponegoro.

Hilger PA. 1996. Penyakit sinus paranasalis. Dalam : Boies, Buku Ajar Penyakit THT. Edisi Bahasa Indonesia, alih bahasa: Carolin Wijaya, edisi 6. Jakarta EGC, : hal $240-259$.

International Consensus Report on Diagnosis and Management of Rhinitis. International Rhinitis Management Working Group Allergy. 1994;49(Suppl. 19):1 34.

Morkjaroenpong V. et al. 2002. Environmental tobacco smoke exposure and nocturnal symptoms among inner-city children with asthma. J Allergy Clin Immunol ; 1:147 - 153

Mullol J, et al. 2008. Allergic rhinitis and its impact on asthma update (ARIA 2008). The perspective from Spain. J Investig Allergol Clin Immunol. Vol. 18(5): 327 334. Di akses pada tanggal 09 Desember 2017 http://www.jiaci.org/issues/vol18i ssue5/2.pdf

Munawaroh S, Munasir Z, Bramantyo B, Pudjiadi A. 2008. Insidens dan karakteristik otitis media efusi pada rinitis alergi anak. Sari Pediatri.; 10(3): hal 214.

Notoatmodjo, S. 2010. Metodologi Penelitian Kesehatan. Jakarta : Rhineka Cipta. 
Nursalam. 2003. Konsep dan Penerapan Metodologi Penelitian Ilmu Keperawatan Pedoman Skripsi, Tesis dan Instrumen Penelitian Keperawatan. Jakarta : Salemba.

Pawankar R, Canonica GW, Holgate ST, Lockey RF. 2011. Allergic rhinitis, allergic conjunctivitis, and rhinosinusitis. In : World Allergy Organization White Book On Allergy. United Kingdom: World Allergy Organization; . p 27.

Pelikan Z. 1994. Participation of allergy [ALL] and non-specific hyperreactivity [N-SH] components in rhinitis. Allergy Clin Immunol News; No 2:415

Plaut M, valentine M. 2005. Clinical practice allergic rhinitis. The New England Journal of Medicine [Internet].; 353: 1934 - 1944.

Pramono. 1999. Rinitis Alergi Perenial Sebagai Salah Satu Faktor risiko Sinusitis Maksila Kronis. Semarang: Fakultas kedokteran Universitas Diponegoro.

Primartono. 2003. Hubungan faktorfaktor predisposisi dengan sinusitis maksila kronik. Semarang: Fakultas Kedokteran Universitas Diponegoro.

Rahmawati N, Suprihati, Muyassaroh. 2011. Faktor risiko yang mempengaruhi disfungsi tuba eustachius pada penderita rinitis alergi persisten. Semarang: Fakultas Kedokteran Universitas Diponegoro.

Rank MA, Wollan P, Kita H, Yawn BP. 2010. Acute exacerbations of chronic rhinosinusitis occur in a distinct seasonal pattern. The Journal of allergy and clinical immunology. USA: American

S Lin, D Reh, S Clipps, L Irani, A Navas. 2011. Allergic rhinitis and secondhand tobacco smoke: a population-based study [Abstract]. Am J Rhinol Allergy. 25(2):e66 - 71.: Di akses pada tanggal 13 Desember 2017 http://www.ncbi.nlm.nih.gov/pub med/21679502
Sarwono, J. 2009. Statistik Itu Indah. Yogyakarta : CV Andi Offset.

Spector SL. 1997. Overview of comorbid association of allergic rhinitis. J Allergy Clin Immunol; 99: S $773-800$

Sujarweni, V. Wiratna. 2014. Metode Penelitian : Lengkap, Praktis, dan Mudah Diphami. Yogyakarta : Pustaka Baru Press.

Suprihati, Setiadi. 2010. Positive Skin Prick Test, Sinus Mucosal Eosinophil and Duration of Symptoms as Risk Factor of the Severity of Chronic Rhinosinusitis. The 14th Asian Research Symposium in Rhinology, $26-27$ March 2010, Hochiminh City, Vietnam.

Suprihati. 1997. Patogenesis dan diagnosis sinusitis. Dalam: Herry Supardjo, Suprihati, Soewito, Med D Loew, eds. Naskah Simposium Sinusitis dan penatalaksanaannya, Semarang.

Suprihati. 2001. Comparison between 8 $\mathrm{mg}$ chlorpeniramine and $10 \mathrm{mg}$ cetirizine once daily for treating perennial allergic rhinitis. ORLI; 34: $25-32$.

Suprihati. 2005. The prevalence of allergic rhinitis and its relation to some risk factors among 13 - 14 year old student in semarang, Indonesia. Otolaryngologica Indonesian.; XXXV (2): 37 - 70.

Suprihati. 2011. Manajemen pilek dan alergi, pencegahan dan peningkatan kualitas hidup. Dalam Naskah Pidato Pengukuhan Guru Besar Fakultas kedokteran Universitas Diponegoro.

Taher YA. 2010. Allergen specific subcutaneous immunotherapy in allergic asthma : immunologic mechanism and improvement. Di akses pada tanggal 16 Desember 2017

http://www.libyanjournalofmedici ne.net/index.php/ljm/article/view $55303 / \mathrm{html} 12$

The Asthma Center. 2013. Pet allergy. It's more manageable than you think [internet]. Di akses pada tanggal 16 Desember 2017 
http://www.theastmacenter.org/i ndex.php/newsletter/pet allergy/ Togias AG. et al. 1995. Cold dry airinduced rhinitis: effect of inhalation and exhalation through the nose. J Appl Physiol; 79:467 $-471$.

Utama, D.S. 2010.Hubungan antara jenis aeroallergen dengan manifestasi klinis rinitis alergika [Tesis]. Semarang: Fakultas Kedokteran Universitas Diponegoro.

Wright A L. et al. 2012 Epidemiology of physician diagnosed allergic rhinitis in childhood. 94:895 901. Di akses pada tanggal 16 Desember 2017

http://www.ncbi.nlm.nih.gov/pub med/7971008 